\title{
PENGARUH PEMAHAMAN KONSEP MATEMATIKA TERHADAP KEMAMPUAN PENGGUNAAN APLIKASI SPSS MATA KULIAH STATISTIK
}

\author{
Auliana Nasution \\ UMN AI Washliyah, UNP \\ e-mail: liana96782@gmail.com
}

\begin{abstract}
Abstrak
Penelitian ini bertujuan untuk mengetahui dan menjelaskan pengaruh pemahaman konsep matematika terhadap penggunaan aplikasi SPSS. Jenis penelitian ini adalah assosiatif, alat pengumpulan data menggunakan tes yang disebarkan kepada 35 orang sampel yang diambil secara acak. Analisis data yang dipakai adalah analisis deskriptif dan analisis regresi linier sederhana dengan menggunakan program SPSS 20 for Windows. Hasil penelitian menunjukkan variabel pemahaman konsep matematika signifikan terhadap kemampuan penggunaan Aplikasi SPSS pada mata kuliah statistik, dengan demikian maka hipotesis $\left(\mathrm{H}_{0}\right)$ diterima.
\end{abstract}

Kata kunci : Pemahaman, Konsep Matematika, Aplikasi SPSS

\begin{abstract}
This study aims to determine and explain the effect of understanding mathematical concepts on the use of SPSS applications. This type of research is associative, the data collection tool uses a test that is distributed to 35 people randomly taken samples. Data analysis used is analysis descriptive and simple linear regression analysis using SPSS 20 for Windows. The results of the study show that the understanding of mathematical concepts is significant for the ability to use the SPSS Application.
\end{abstract}

Keywords: Understanding, Mathematical Concepts, SPSS Applications

\section{Pendahuluan}

Gilbert dalam Iskandar (2012) menyatakan bahwa pemahaman matematis adalah kemampuan menjelaskan situasi dengan kata-kata yang berbeda dan dapat menginterpretasikan atau menarik kesimpulan dari tabel, data, grafik dan sebagainya. Oleh karena itu pemahaman matematis dapat menumbuhkan keaktifan siswa dalam mencari ide-ide matematikanya (Kilpatrick \& Swafford, 2002). Menurut Kilpatrick (2001) pemahaman konsep matematika yaitu menyatakan ulang sebuah konsep yang dipelajari, menggunakan, memanfaatkan, dan memilih prosedur; memberi contoh dan non contoh; mengaplikasikan konsep atau algoritma pemecahan masalah; membandingkan dengan penyajian contoh dalam berbagai representasi. Pada tingkat pemahaman yang mendalam siswa mulai mampu untuk membuat keterkaitan antara ide-ide matematika dan membuat generalisasi dari suatu konsep (Potter \& Kustra, 2012). Konsep merupakan suatu ide abstraksi yang mewakili objek-objek, kejadian-kejadian, kegiatan-kegiatan, atau hubungan-hubungan yang mempunyai atribut-atribut yang sama (Sagala, 2009). Apabila siswa benar-benar memahami masalah, mereka bisa menjelaskan, menafsirkan, menerapkan, memiliki perspektif, berempati dan memiliki pengetahuan diri yang meliputi penggunaan dan aplikasi dalam situasi otentik berdasarkan pengetahuan konseptual dan procedural (Ghazali \& Zakaria, 2011). 
Matematika sebagai suatu bidang ilmu yang merupakan alat pikir, berkomunikasi, alat untuk memecahkan berbagai persoalan praktis, yang unsur-unsurnya logika dan instituisi, analisis dan konstruksi, generalisasi dan individualitas serta mempunyai cabang-cabang antara lain aritmatika, geometri, dan analisis (Uno, 2008). Menurut Sujatmikowati (2010) menyebutkan bahwa pelajaran matematika merupakan salah satu disiplin ilmu yang dapat meningkatkan kemampuan berfikir dan berargumentasi.

Salah satu cabang ilmu matematika yang menggunakan pengetahuan dan procedural adalah ilmu statistik. Statistic merupakan disiplin ilmu yang berguna untuk kemajuan ilmu dan teknologi, oleh karena itu kita dituntut untuk memahami statistic lebih mendalam. Menurut Webster dalam Susanti (2010) statistika didefenisikan sebagai cabang matematika yang berkaitan dengan pengumpulan, analisis, interpretasi dan penyajian dari sejumlah data numeric. Dengan demikian, data statistic adalah semua data yang dapat dikumpulkan, diorganisir dan diolah dengan cara tertentu. Pendekatan atau metode statistik adalah bagian yang tak terpisahkan dari pendekatan atau paradigm kuantitatif. Paradigm kuantitatif atau biasa disebut paradigm tradisional, positivis, eksperimental dan empirikis menempatkan statistika sebagai teknik analisis atau prosedur penting untuk menguji teori. Paradigm kuantitatif melahirkan berbagai jenis atau metode penelitian kuantitatif (Kadir, 2016). Menurut Creswell (2013), penelitian kuantitatif merupakan metode-metode untuk menguji teori-teori dengan cara meneliti hubungan antar variabel. Variabel-variabel diukur dengan instrument penelitian yang menghasilkan data berbentuk angka-angka dan dianalisis dengan prosedur statistik.

Pengolahan data statistik hingga menghasilkan informasi yang relevan menjadi lebih cepat dan akurat jika dapat memanfaatan media pembelajaran. Media pembelajaran juga dapat memudahkan pemahaman siswa terhadap kompetensi yang harus dikuasai, materi yang harus di pelajari dan dapat mempertinggi hasil belajar (Mulyanta \& Marlon, 2009). Salah satu media yang dapat digunakan adalah computer. Perkembangan teknologi computer dapat menyentuh kegiatan pengolahan data statistik dengan aplikasi khusus seperti SPSS.

SPSS adalah salah satu program computer yang khusus di buat untuk mengolah data dengan metode statistik tertentu (Santoso, 2018). Pemilihan SPSS dalam pengolahan data statistik ini lebih dikarenakan fakta bahwa SPSS adalah software statistik terpopuler di dunia, termasuk di Indonesia. Keunggulan lain adalah tampilan SPSS yang sudah setara dengan Excel, bahkan dalam pengolahan grafik-grafik statistiknya sudah melampaui software andalan Microsoft tersebut, selain itu penggunaan menu-menu di SPSS sangat user friendly, lebih mudah dan simple dibandingkan Minitab yang mengharuskan pengguna membuka banyak windows (Santoso, 2018).

Berdasarkan penjelasan di atas, maka penelitian ini bertujuan untuk mengetahui dan menjelaskan pengaruh pemahaman konsep matematika terhadap kemampuan penggunaan Aplikasi SPSS pada mata kuliah statisik. Karena kemampuan memahami konsep, membedakan sejumlah konsep-konsep yang saling terpisah serta kemampuan melakukan perhitungan secara bermakna pada situasi atau permasalahan-permasalahan yang lebih luas merupakan tujuan dari pemahaman matematis (Trias, 2010). Adapun hipotesis dalam penelitian ini adalah diduga pengaruh yang signifikan antara pemahaman konsep matematika (X) terhadap kemampuan penggunaan Aplikasi SPSS (Y).

Penelitian yang terkait dengan penelitian ini adalah penelitian Agus Jayadi dan Zul Anwar (2017) yang menyatakan bahwa aplikasi SPSS berpengaruh terhadap peningkatan keterampilan mahasiswa dalam mengolah data statistik. Sedangkan penelitian Dia Novitasari (2016) menyatakan bahwa multimedia interaktif berpengaruh terhadap kemampuan pemahaman konsep matematis siswa.

\section{Metode}

Penelitian ini adalah penelitian asosiatif yaitu penelitian yang bertujuan untuk mengetahui pengaruh ataupun juga hubungan antara dua variabel atau lebih. Subjek penelitian adalah mahasiswa Ekonomi semester VI Jurusan Manajemen UMN Al Washliyah, dengan sampel 
sebanyak 35 orang yang pengambilannya menggunakan teknik purposive sampling. Untuk mengumpulkan data dilakukan observasi dan tes kemudian di analisis menggunakan teknik analisis deskriprif dengan mencari harga rata-rata, standar deviasi, dan mean. Teknik pengujian hipotesis yang digunakan adalah regresi sederhana dengan uji persyaratan analisis data yang digunakan adalah uji Normalitas dan homogenitas.

Untuk memberi gambaran, maka desain penelitian ditunjukkan melalui gambar berikut:

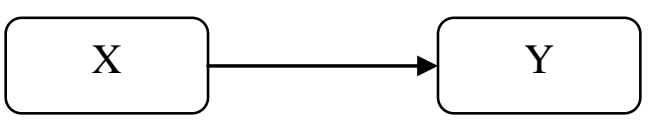

Keterangan:

Gambar 1. Desain Penelitian

$X$ : pemahaman konsep

Y : kemampuan penggunaan aplikasi SPSS

\section{Hasil dan Pembahasan}

Untuk mengetahui pengaruh pemahaman konsep matematika terhadap kemampuan menggunakana aplikasi SPSS mata kuliah statistik, mahasiswa diberikan tes pemahaman konsep statistik dan ditindak lanjuti dengan menerapkannya pada aplikasi SPSS. Hasil tes kemudian diolah menggunakan aplikasi SPSS dan diperoleh data dari hasil pengukuran tes tersebut sebagai berikut :

Tabel 1. Descriptive Statistics

\begin{tabular}{|c|c|c|c|c|c|}
\hline & & $\begin{array}{l}\mathrm{N} \\
\text { Statistic }\end{array}$ & $\begin{array}{l}\text { Mean } \\
\text { Statistic }\end{array}$ & Std. Error & $\begin{array}{l}\text { Std. Deviation } \\
\text { Statistic }\end{array}$ \\
\hline $\begin{array}{l}\text { Pemahaman } \\
\text { Matematika }\end{array}$ & Konsep & 35 & 80,7714 & 1,34607 & 7,96347 \\
\hline $\begin{array}{l}\text { Kemampuan } \\
\text { Aplikasi SPSS }\end{array}$ & Penggunaan & 35 & 83,0286 & 1,25791 & 7,44188 \\
\hline Valid N (listwise) & & 35 & & & \\
\hline
\end{tabular}

Secara deskriptif menunjukkan bahwa hasil pemahaman konsep mahasiswa memperoleh rata-rata (mean) 80,77 dan standar deviasi 1,346, dan rata-rata (mean) mahasiswa menggunakan aplikasi SPSS 83,0286 dan standar deviasi 1,257. Berdasarkan hasil tes akhir tersebut disimpulkan bahwa pemahaman konsep matematika sudah baik dengan demikian kemampuan penggunaan aplikasi SPSS mata kuliah statistik juga baik.

Selanjutnya dilakukan uji prasyarat untuk mengetahui jenis data sebelum dilakukan analisis hipotesis.

\section{Uji Prasarat}

\section{Uji Normalitas}

Tabel 2. One-Sample Kolmogorov-Smirnov Test

\begin{tabular}{|c|c|c|c|}
\hline & & $\begin{array}{l}\text { Pemahaman } \\
\text { Konsep } \\
\text { Matematika }\end{array}$ & $\begin{array}{l}\text { Kemampuan } \\
\text { Penggunaan } \\
\text { Aplikasi SPSS }\end{array}$ \\
\hline $\mathrm{N}$ & & 35 & 35 \\
\hline & Mean & 80,7714 & 83,0286 \\
\hline Normal Parameters & Std. Deviation & 7,96347 & 7,44188 \\
\hline Most Extreme Differences & Positive & , 122 &, 085 \\
\hline Kolmogorov-Smirnov Z & Negative & $\begin{array}{l}-, 161 \\
, 954\end{array}$ & $\begin{array}{l}-, 181 \\
1,068\end{array}$ \\
\hline
\end{tabular}




\begin{tabular}{lll}
\hline Asymp. Sig. (2-tailed) &, 322 &, 204 \\
a. Test distribution is Normal. & & \\
b. Calculated from data. & & \\
\hline
\end{tabular}

Hipotesis yang akan diuji dalam kasus ini adalah :

$\mathrm{H}_{0}$ : Distribusi populasi normal, jika probabilitas $>0,05, \mathrm{H}_{0}$ diterima

$\mathrm{H}_{1}$ : Distribusi populasi tidak normal, jika probabilitas $\leq 0,05, \mathrm{H}_{0}$ ditolak

Dari output di atas, untuk pemahaman konsep matematika diperoleh Tes Statistik sebesar 0,954 dan Asymp. Sig (2-tailed) $=0,322$ atau dapat ditulis sebagai nilai probabilitas ( $p$-value) $=$ $0,322>0,05$ atau $\mathrm{H}_{0}$ diterima. Sedangkan untuk kemampuan penggunaan Aplikasi SPSS diperoleh Tes Statistik sebesar 1,068 dan Asymp. Sig (2-tailed) = 0,204 atau dapat ditulis sebagai nilai probabilitas $(p$-value $)=0,204>0,05$ atau $\mathrm{H}_{0}$ diterima. Dengan demikian, data berdistribusi normal.

\section{Uji Homogenitas}

Tabel 3. Test of Homogeneity of Variances

\begin{tabular}{llll}
\hline Levene Statistic & $\mathrm{df1}$ & $\mathrm{df2}$ & Sig. \\
\hline 2,406 & 9 & 16 &, 060 \\
\hline
\end{tabular}

Dari hasil analisis pada tabel Test of Homogeneity of Variances, diperoleh $\mathrm{F}=2,406$; $\mathrm{db} 1$ $=9 ; \mathrm{db}=16$ dan $p$-value $=0,060>0,05$ atau $\mathrm{H}_{0}$ diterima. Dengan demikian, data pemahaman konsep matematika dinyatakan homogen.

Dalam hal ini uji prasyarat telah memenuhi dan selanjutnya akan dilakukan analisis menggunakan persamaan regresi linier sederhana sebagai berikut :

Tabel 4. Persamaan Regresi Linier

\begin{tabular}{|c|c|c|c|c|c|c|c|c|}
\hline \multirow{2}{*}{\multicolumn{2}{|c|}{ Model }} & \multicolumn{2}{|c|}{$\begin{array}{l}\text { Unstandardized } \\
\text { Coefficients }\end{array}$} & \multirow{2}{*}{$\begin{array}{l}\text { Standardized } \\
\text { Coefficients } \\
\text { Beta }\end{array}$} & \multirow[b]{2}{*}{$\mathrm{t}$} & \multirow{2}{*}{ Sig. } & \multicolumn{2}{|c|}{$\begin{array}{l}95,0 \% \text { Confidence } \\
\text { Interval for B }\end{array}$} \\
\hline & & B & $\begin{array}{l}\text { Std. } \\
\text { Error }\end{array}$ & & & & $\begin{array}{l}\text { Lower } \\
\text { Bound }\end{array}$ & $\begin{array}{l}\text { Upper } \\
\text { Bound }\end{array}$ \\
\hline \multirow[b]{2}{*}{1} & $\begin{array}{l}\text { (Constant) } \\
\text { Pemahaman }\end{array}$ & 40,914 & 10,956 & & 3,735 & ,001 & 18,625 & 63,204 \\
\hline & $\begin{array}{l}\text { Konsep } \\
\text { Matematika }\end{array}$ & ,521 & 135 & ,558 & 3,862 & ,000 & 247 & ,796 \\
\hline
\end{tabular}

a. Dependent Variable: Kemampuan Penggunan Aplikasi SPSS

Berdasarkan hasil output SPSS di atas, konstanta dan koefisien persamaan regresi linier diperoleh $Y=40,9191+0,521 \mathrm{X}$ dari hasil analisis diperoleh $t_{\text {hit }}=3,862$ dan $p$-value $=$ 0,000 , dengan demikian sig $t<0,005$ maka $H_{0}$ ditolak berarti terdapat pengaruh pemahaman konsep matematis terhadap kemampuan penggunaan SPSS Mata Kuliah Statistik. Dari persamaan regresi tersebut dapat dinyatakan bahwa pemahaman konsep matematika siswa sebesar 40,9191, dengan koefisien regresi 0,521 yang menyatakan bahwa pemahaman konsep matematika akan mempengaruhi kemampuan penggunaan aplikasi SPSS mata kuliah statistik sebesar 0,521 dan peningkatan pemahaman konsep matematika akan mempengaruhi kemampuan penggunaan aplikasi SPSS sebesar 0,521 jika variabel $x$ sama dengan nol dengan nilai konstanta kenaikan pemahaman konsep matematika mahasiswa sebesar $40,9191$.

\section{Uji Linieritas Regresi dan signifikansi persamaan regresi}

Pengujian linieritas dan signifikansi persamaan regresi ditentukan berdasarkan tabel berikut Tabel 5. Uji Anacova 


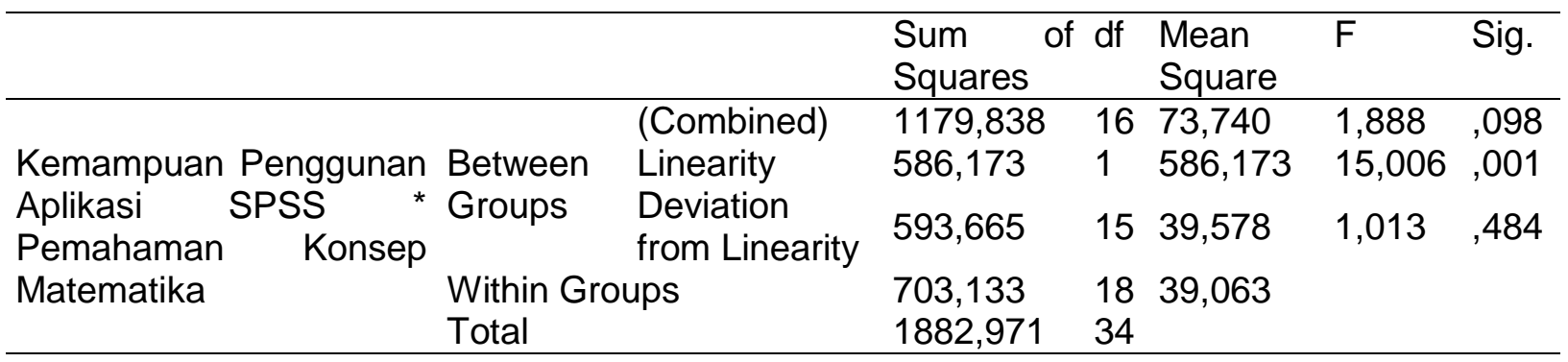

Hipotesis statistik:

$H_{0}: Y=\alpha+\beta X$ (regresi linier)

$H_{1}: Y \neq \alpha+\beta X$ (regresi non linier)

Uji linieritas persamaan garis regresi yaitu $F_{\text {hit }}(T C)=1,013$, dengan $p$-value $=0,484>0,05$. $\mathrm{Hal}$ ini berarti $\mathrm{H}_{0}$ diterima atau persamaan regresi $\mathrm{Y}$ atas $\mathrm{X}$ adalah linier atau berupa garis linier.

Tabel 6. ANOVA ${ }^{\mathrm{a}}$

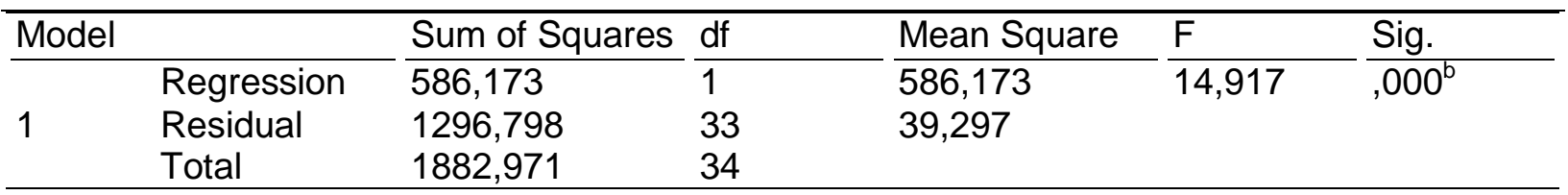

a. Dependent Variable: Kemampuan Penggunan Aplikasi SPSS

b. Predictors: (Constant), Pemahaman Konsep Matematika

Hipotesis statistik :

$\mathrm{H}_{\mathrm{o}}: \beta=0$ (regresi tak berarti)

$\mathrm{H}_{1}: \beta \neq 0$ (regresi berarti)

Uji signifikansi persamaan garis regresi diperoleh $F_{\text {hit }}(b / a)=14,917$, dan $p$-value $=0,000<$ 0,05 atau $\mathrm{H}_{0}$ ditolak. Dengan demikian, regresi $\mathrm{Y}$ atas $\mathrm{X}$ adalah signifikan atau pemahaman konsep matematika berpengaruh terhadap penggunaan aplikasi SPSS Mata Kuliah Statistik.

Tabel 7. Uji Signifikansi Koefisien korelasi X dan Y

\begin{tabular}{llllllllll}
\hline Model & $\mathrm{R}$ & $\mathrm{R}$ & Adjusted & Std. & Error & Change Statistics \\
Square & $\mathrm{R}$ Square & $\begin{array}{l}\text { of } \\
\text { Estimate }\end{array}$ & & $\begin{array}{l}\mathrm{R} \\
\text { Square } \\
\text { Change }\end{array}$ & $\begin{array}{l}\mathrm{F} \\
\text { Change }\end{array}$ & df1 df2 & $\begin{array}{l}\text { Sig. } \\
\text { Change }\end{array}$ \\
\hline 1 & $, 558^{\mathrm{a}}, 311$ &, 290 & 6,269 &, 311 & 14,917 & 1 & 33 &, 000 \\
\hline
\end{tabular}

a. Predictors: (Constant), Pemahaman Konsep Matematika

Hipotesis statistik

$\mathrm{H}_{0}: \rho=0$

$\mathrm{H}_{1}: \rho \neq 0$

Uji signifikansi koefisien korelasi $\left(r_{\mathrm{xy}}\right)=0,558$ dan $F_{\text {hit }}\left(F_{\text {change }}\right)=14,917$, dengan $p$-value $=0,000<0,05$. Hal ini berarti $\mathrm{H}_{0}$ ditolak. Dengan demikian koefisien korelasi $\mathrm{X}$ dan $\mathrm{Y}$ adalah berarti atau signifikan. Sedangkan koefisien determinasi $(R$ Square) $=0,311$, yang berarti bahwa $31,1 \%$ variasi variabel kemampuan penggunaan SPSS Mata Kuliah Statistik dipengaruhi oleh variabel pemahaman konsep matematis, dengan kata lain banyak factorfaktor yang dapat mempengaruhi kemampuan menggunakan SPSS selain dari factor pemahaman konsep matematis. Namun demikian pemahaman konsep dasar matematika 
merupakan kemampuan yang harus dikuasai telebih dahulu sebelum mempelajari matematika lanjut.

\section{Simpulan dan Saran}

Berdasarkan hasil perhitungan dan analisis data di atas maka dapat disimpulkan bahawa pemahaman konsep matematika berpengaruh terhadap kemampuan penggunaan SPSS Mata kuliah Statistik mahasiswa semester VI Jurusan Manajemen UMN Al Washliyah. Dan sesuai dengan koefisien determinasi yaitu 31,1\% pemahaman konsep matematika mempengaruhi penggunaan SPSS Mata Kuliah Statistik dan 68,9\% dipengaruhi oleh faktor lain.

Adapun saran yang ingin di sampaikan penulis adalah hendaknya dosen dapat lebih meningkatkan pemahaman konsep matematika mahasiswa agar mahasiswa dapat memecahkan masalah-masalah yang lebih sulit. Dan di harapkan penelitian selanjutnya dapat menggunakan variabel-variabel lain yang dapat mempengaruhi kemampuan penggunaan SPSS mata kuliah statistik.

\section{Daftar Pustaka}

Creswell, Jhon W. (2013). Research Design : Pendekatan Kualitatif, Kuantitatif, dan Mixed. Ter. Achmad Fawaid. Yogyakarta : Pustaka Pelajar.

Iskandar, A. (2012). Peningkatan Kemampuan Pemahaman dan Komunikasi Matematika Siswa SD Melalui Pendekatan Realistic Mathematics Education (RME). Prosiding Seminar Nasional Matematika dan Pendidikan Matematika FMIPA UNY. Yogyakarta : 10 Nopember 2012.

Kadir. (2016). Statistika Terapan Konsep, contoh dan Analisis Data dengan Program SPSS/Lisrel dalam Penelitian. Jakarta : PT. Rajagrafindo.

Mulyanta \& Marlon. (2009). Tutorial Pembangunan Multimedia Interaktif. Yogyakarta : Universitas Atmajaya.

Trias, I. (2010). Peningkatan Pemahaman Konsep Matematika Siswa Melalui Pemberian Tugas Concept Mapping pada Akhir Pembelajaran. Skripsi FPMIPA UPI Bandung. Tidak diterbitkan

Santoso, Singgih. (2018). Menguasai Statistik dengan SPSS 25.PT Elex Media Komputindo : Jakarta.

Sujatmikowati, Ani. (2010). Peningkatan Kemampuan Pemahaman dan Generalisasi Siswa dalam Matematika melalui Pembelajaran dengan Pendekatan Open-Ended. Tesis Pasca Sarjana UPI Bandung. Tidak Diterbitkan.

Susanti, Meila Nur Indah. (2010). Statistik Deskriptif dan Induktif. Graha ilmu : Yogyakarta

Uno, Hamzah. (2008). Model Pembelajaran Menciptakan Proses Belajar Mengajar yang Kreatif dan Efektif. Jakarta : Bumi Aksara 